Egypt. Acad. J. Biolog. Sci., 11(1): 49- 62 (2019)

Egyptian Academic Journal of Biological Sciences

D. Histology \& Histochemistry

2090 - 0775

www.eajbsd.journals.ekb.eg

\title{
Microscopically Studies on the Liver of Acanthodactylus boskianus lizard
}

Allam A. M. Nafady ${ }^{1}$ and Eatemad A. Awadalla*2

1-Department of Pathology, Faculty of Veterinary Medicine, Assiut University, Egypt

2-Department of Zoology Faculty of Science Aswan University, Aswan, 81528 Egypt.

E. Mail.: Eatemad2000@Aswu.edu.eg

ARTICLE INFO

Article History

Received: 25/2/2019

Accepted: 1/4//2019

\section{Keywords:}

Acanthodactylus

boskianus, Liver,

light and electron microscopy

\section{ABSTRACT}

The aim of this study was to investigate the histological and fine structure of the liver of Acanthodactylus boskianus during the hibernation period, using ten adult specimens captured from sandy areas of Aswan Governorate, Egypt. Specimens of liver were fixed for light and transmission electron microscope to study the hepatic architecture during this period. In addition to haematoxylin and eosin stain, the histochemical and special stains were used. The hepatocytes are arranged in hepatic plates. The radial arrangement of hepatic cords around the central vein is generally not apparent. The several-cell-thick plate type showed with multi-layered of hepatocytes separated by narrow tortuous capillaries networks, sinusoids that are localized in the space between hepatic plates. The hepatic cells of Acanthodactylus boskianus under light and T.E.M. are similar to those of other vertebrates (birds and mammals), except for the presence of melano- macrophages.

\section{INTRODUCTION}

The Reptilia class is a prominent part of all terrestrial assemblage, containing 9,084 species by the latest count (Uetz and Hallermann, 2010). Reptiles are represented by four orders: Crocodilia, Rhynchocephalia; Squamata and Testudinata. The Squamata order includes lizards, land animals with well-defined eating habits (Vitt et al., 2003).

Reptiles are very important for the maintenance of ecosystems. For this reason, many papers have been published on their geographic and population distribution and ecological and behavioral aspects. However, few studies have been published on the morphological aspects of these animals. These factors are important for their correct classification and comparison against other phylogenetically related species and to establish their interaction with the biome where they live (Firmiano et al., 2011; Hamdi et al., 2014).

The genus Acanthodactylus is commonly known as the fringe-fingered lizards and is the largest genus in the family Lacertidae with over 40 described species (Uetz, 2013). Members of this genus are small- to medium-sized, diurnal, terrestrial, and oviparous species that inhabit semi-arid to desert ecosystems from the Iberian Peninsula, through North Africa, to the Middle East and West India, 
including Cyprus and the Arabian Peninsula (Sindaco and Jeremc ${ }^{2}$ enko, 2008).The latter three studies divided the genus into species groups, a division that is commonly used today (Tamar, 2014).

The Acanthodactylus boskianus species group is a striking case of taxonomic uncertainty. Although it is a small group of only three species, its geographical range is the largest in the genus. It includes Acanthodactylus boskianus (Daudin, 1802), Acanthodactylus schreiberi (Boulenger, 1878) and Acanthodactylus nilsoni (RastegarPouyani, 1998). Acanthodactylus boskianus is the most widespread species of its genus ranging through North Africa (Salvador, 1982). Acanthodactylus boskianus has been divided into five subspecies: $A$. boskianus boskianus (Daudin, 1802) from the Nile delta and parts of Sinai, A. boskianus asper (Audouin, 1827) from much of the distribution range of the species, A. boskianus euphraticus (Boulenger, 1919) from Iraq, A. boskianus khattensis from Mauritania and A. boskianus nigeriensis from Niger (Trape et al., 2012). Animals in Aswan are A. b. asper.

The liver has multiple and complex functions. It is the site of numerous metabolic processes, because it receives all the material absorbed by the intestines, except for a certain quantity of lipids transported by the lymph nodes (Samuelson, 2007). The liver is one of the most important organs in the organism, because it metabolizes stores, synthesizes and eliminates the substances absorbed. It also produces bile, an exocrine secretion of the hepatic cells, which plays a key role in the digestion and absorption of fats (Pough et al., 1999). Knowledge of reptiles' liver morphology is a valuable source of information for clinicians. It is fundamental for the proper diagnosis of reptile diseases. Schaffner (Schaffner, 1998) analyzed the livers of reptiles in general, but few studies have examined the liver of Acanthodactylus boskianus. Therefore, the purpose of this study was to characterize the liver of this species microscopically during hibernation, to shed light on the morphological aspects of this class of reptile.

\section{MATERIALS AND METHODS}

Ten adult specimens (male and female) of Acanthodactylus boskianus lizard were collected in February 2018. They were captured from sandy areas of Aswan Governorate and identified by Dr. Sherif Baha El Din, Environmental Consultant, Ecologist, Ornithologist, Herpetologist, and President Nature Conservation Egypt. After capture, the specimens were taken to the Zoological Laboratory of Science Faculty, Aswan University, where they were anaesthetized and dissected according to the Animal Care and Use Committee, University of Aswan. After lizards dissection the liver specimens rapidly excised, and immediately fixed for light and electron microscopy.

After fixation in neutral buffer formalin was completed, the specimens were washed, dehydrated in ascending grades of ethyl alcohol, cleared in methyl benzoate and finally embedded in paraffin wax, the paraffin blocks were sectioned at a thickness of 5-6 $\mu \mathrm{m}$. Then the following stains were utilized:

1. Harris's haematoxylin and eosin (Harris, 1990).

2. Masson 'trichrome sta in (Lillie, 1940) for the collagenous fibers.

3. Periodic acid Schiff's (PAS) technique for general carbohydrates, Mc Manus (1946). 


\section{Electron Microscopy:}

For ultrastructural examination, the samples processed examined and photographed in E. microscopic Unit in Assiut University. Small pieces of liver were immediately immersed in $4 \mathrm{~F} 1 \mathrm{G}$ in phosphate buffer $(\mathrm{pH}$ 7.2) fixation mixture for $3 \mathrm{hr}$ at $4^{\circ} \mathrm{C}$ then post-fixed in $1 \% \quad \mathrm{OsO} 4$ (Osmium tetroxide) at $4^{\circ} \mathrm{C}$ for $2 \mathrm{hr}$. The specimens were dehydrated in graded series of ethanol and then embedded in Epon-Araldite mixture in labeled beam capsules. LKB ultramicrotome was used to obtain ultrathin sections (50 $\mathrm{nm}$ thick) which were picked upon 200 mesh naked copper grids. Grids were double stained with uranyl acetate for $1 / 2 \mathrm{~h}$ and lead citrate for 20 $30 \mathrm{~min}$. Scoping the grids was achieved by using TEM 100 CXII electron microscope at $80 \mathrm{KV}$ and photographed by CCD digital camera Model XR- 41 .

\section{RESULTS}

\section{Light Microscopy:}

Light microscopy inspections of the liver section of Acanthodactylus boskianus lizard were illustrated in figure (1). The liver is not as distinctly organized into lobules as in mammals. The functional and basic unit of the lobules is the hepatocytes. The hepatocytes are arranged in severalcell-thick plates or cords which are disposed of in such a way to exhibit a net-like structure arise from a centrally located vein, the central vein to the lobular periphery. The radial arrangement of hepatic cords around the central vein is generally not apparent. The several-cell-thick plate of hepatocytes separated by narrow and short tortuous capillaries networks; sinusoids which are lined with Kupffer cells and endothelial cells. The hepatocytes have a homogenously fine granulated cytoplasm, which embodying peripherally located spherical nuclei, with a conspicuous nucleolus and distinct chromatin particles. Also, existence of a few pigmented cells termed melanomacrophages formed part of the lining of the sinusoids, protruded into the sinusoidal lumen; they were also located in the hepatic parenchyma (Fig. 1a).

The peripheries of a lobule can be defined by portal areas of connective tissue enclosing three main structures, a bile ductule, branches of the hepatic portal vein, and a branch of the hepatic artery. The lumen of the portal vein appears enclosing a few blood cells. The bile ductule has a layer of cuboidal epithelial cells (Fig. 1b). Also, the examination of the Acanthodactylus boskianus liver showed that the liver is covered by a thin layer of connective tissue forming the hepatic capsule (Fig.1c). This capsule is common to all vertebrates and contributes to the division of the parenchyma into structural units, called hepatic lobules. Also, the microscopic analysis revealed that a mild amount of connective tissue stroma, principally of collagenous fibers was detected around the central vein as well as the sinusoidal walls (fig.1d). In addition, each portal area was surrounded by a moderate amount of collagenous network which was continuous with scanty interlobular collagenous fibers (Fig. 1e).

Inspection of the figure (1f) showed that the hepatocytes contained a considerable amount of glycogen granules, appearing in the form of strongly PAS-reactive granules of variable sizes, located mainly in the ground cytoplasm. These granules clumped together into rather massive patches condensed mainly at one pole of the cell.

\section{Electrn Microscopy:}

The electron micrographs of the Acanthodactylus boskianus liver revealed that the hepatocytes have polyhedral shape, each being bounded 
by a distinct cell membrane. As appear in figure (2a) each cell contains peripherally located spherical nucleus limited by a prominent nuclear membrane and surrounded by the ground cytoplasm. In the perinuclear region, a variety of cell organelles or organoids are discerned as well as non-living inclusions.

The cell membrane displayed several modifications or specializations at the different faces of the cell as indicated in the figure (2). The cell membrane gives rise to various forms of intercellular junctions between adjacent cells serving different purposes (Fig. 2a). In addition, at the hepatic cell surface adjacent to a sinusoidal blood space, the cell is delineated from the lining of the sinusoid by a narrow perisinusoidal space, the space of Disse. It is clear that this space separates the sinusoidal endothelium and the adjacent hepatocyte. Therefore, it is bounded on one side by the hepatocyte plasma membrane and on the other side by the sinusoidal endothelium. Worthwhile is that the sinusoidal endothelium plays a pivotal role in the protection of the hepatocyte from the trauma of hepatic blood flow in the sinusoids and it also permits contact between the hepatocytes and blood plasma. This enables the cells to receive certain materials from the circulating blood and empty other materials into this blood. At the contact between the hepatocyte surface and the perisinusoidal space, the cell membrane extends a number of microvilli, usually occupying the perisinusoidal space (Fig. 2c).

Electron micrograph from the biliary region $(2 \mathrm{~d})$ reveals that the cell membranes of two adjacent hepatocytes diverge or become partially separated from each other to form a bile canaliculus. A number of microvilli project from either parenchymal cell into the lumen of the bile canaliculus via which bile secretions are drained from the cells. Also figure (2) revealed that each liver cell has many mitochondria with a spherical form. Their cristae are not so numerous or closely packed a characteristic consistent with moderate oxygen consumption observed in the liver. Another typical component of the liver cell is glycogen. Under the electron microscope, this polysaccharide takes the form of small particles distributed diffusely throughout the cytoplasm. They appear in two forms, nanoparticulate (beta) particles and polyparticulate (alpha) elements or glycogen rosettes, produced by aggregation of the beta particles. Another common cellular component is the lipid droplets, whose quantity varies greatly and they are rounded in their shape (Fig. 2b). In addition, figure (2b) displayed an abundant of granular or rough endoplasmic reticulum is located mainly around the nucleus tending to be arranged in parallel stacks (with narrow lumens).

The sinusoidal space indicates the vascular pole of the hepatocytes (Fig. 3). It is bounded by endothelium of a single layer of cells, essentially comprised of two cellular varieties: (a) the individual endothelial cells which do not overlap as in capillaries and are spread out and fenestrated (Figs. 3a). (b): The Kupffer cells had numerous pseudopods and occasional cup-like indentations. The cytoplasm usually contained numerous types of lysosomes, some of which appeared to be discharging into phagosomes. Many of the larger cells showed vacuoles containing material which resembled the debris in the extracellular medium. Thus, it is likely that these membrane-bound structures 
represented phagosomes with ingested cellular debris (Fig. 3c). Stellate cell or fat-storing cell (Ito cell) was presented in figure (Fig. 3d). This cell was located in the space of Disse and containing lipid droplets

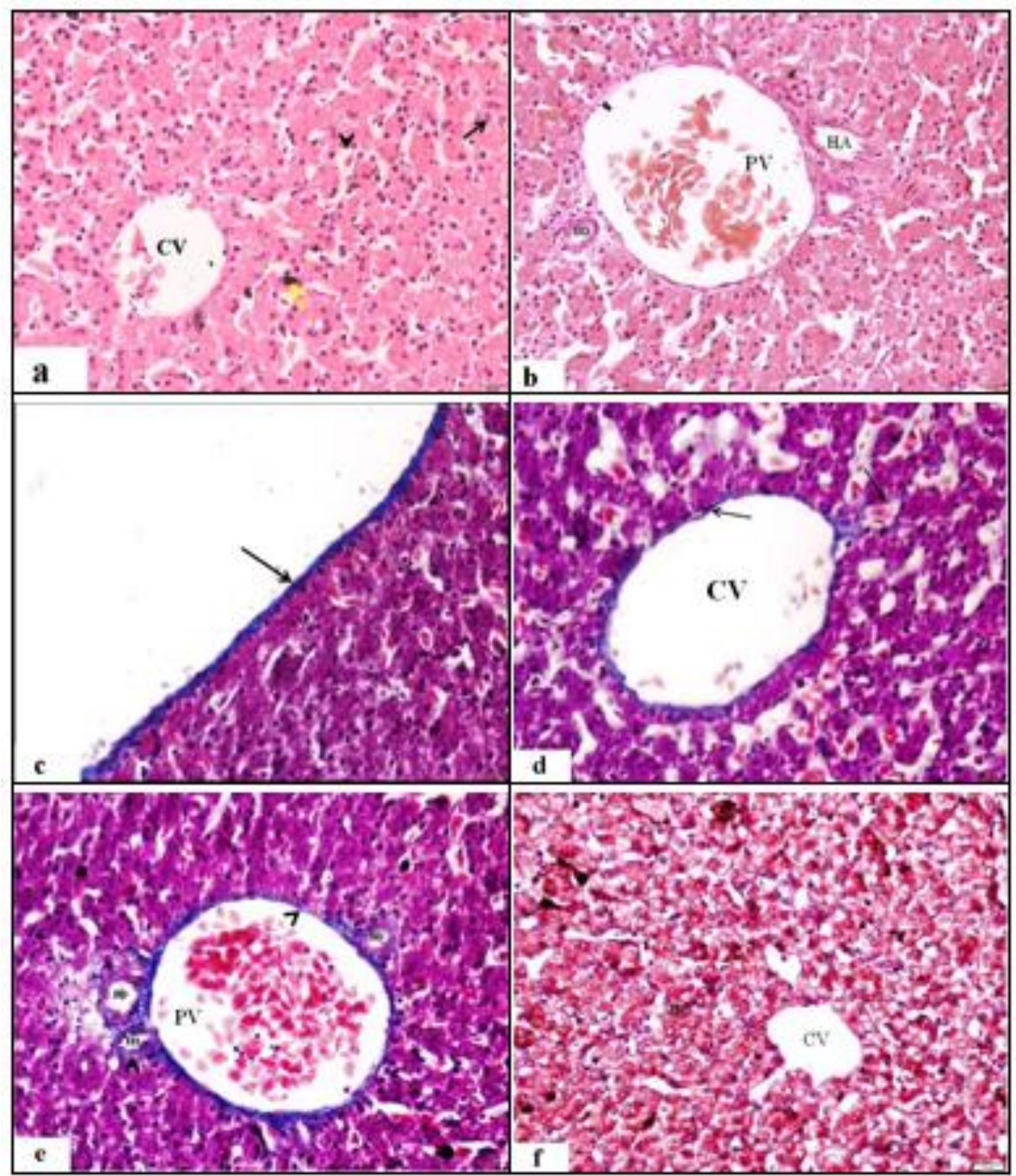

FIg. 1. (a) Light micrograph displaying the liver architecture; showing hepatic cells forming plates of hepatocytes with peripherally located spherical nuclei having prominent nucleoli (black arrow), central vein $(\mathrm{CV})$, blood sinusoids (arrowhead) and melanomacrophages (yellow arrows). (b) Light micrograph displaying the portal area of the liver lobule, containing a portal vein (PV), hepatic artery (HA) and small bile ductules (BD). (c) Micrograph of the hepatic capsule (Glisson's capsule) formed by thin connective tissue capsule (arrow). (d) Micrograph of hepatic lobule showing a wall of central veins (CV) containing a thin layer of the collagenous fibers (arrows) and the wall of blood sinusoids. (e) Light micrograph showing the portal area with small amount of collagenous fibers (arrowhead) in the wall of the portal vein (PV), hepatic artery (HA) as well as bile ductule (BD). (f) Light micrograph showing hepatic cells (HC) containing PAS-positive granules representing the glycogen content of the cells. The granules mostly accumulated at one pole of the cells, reflecting the phenomenon of "glycogen flight". (a\&b: H\&E, 400X; c-e: Masson`stain, 400X; f: PAS-reaction, 400X). 

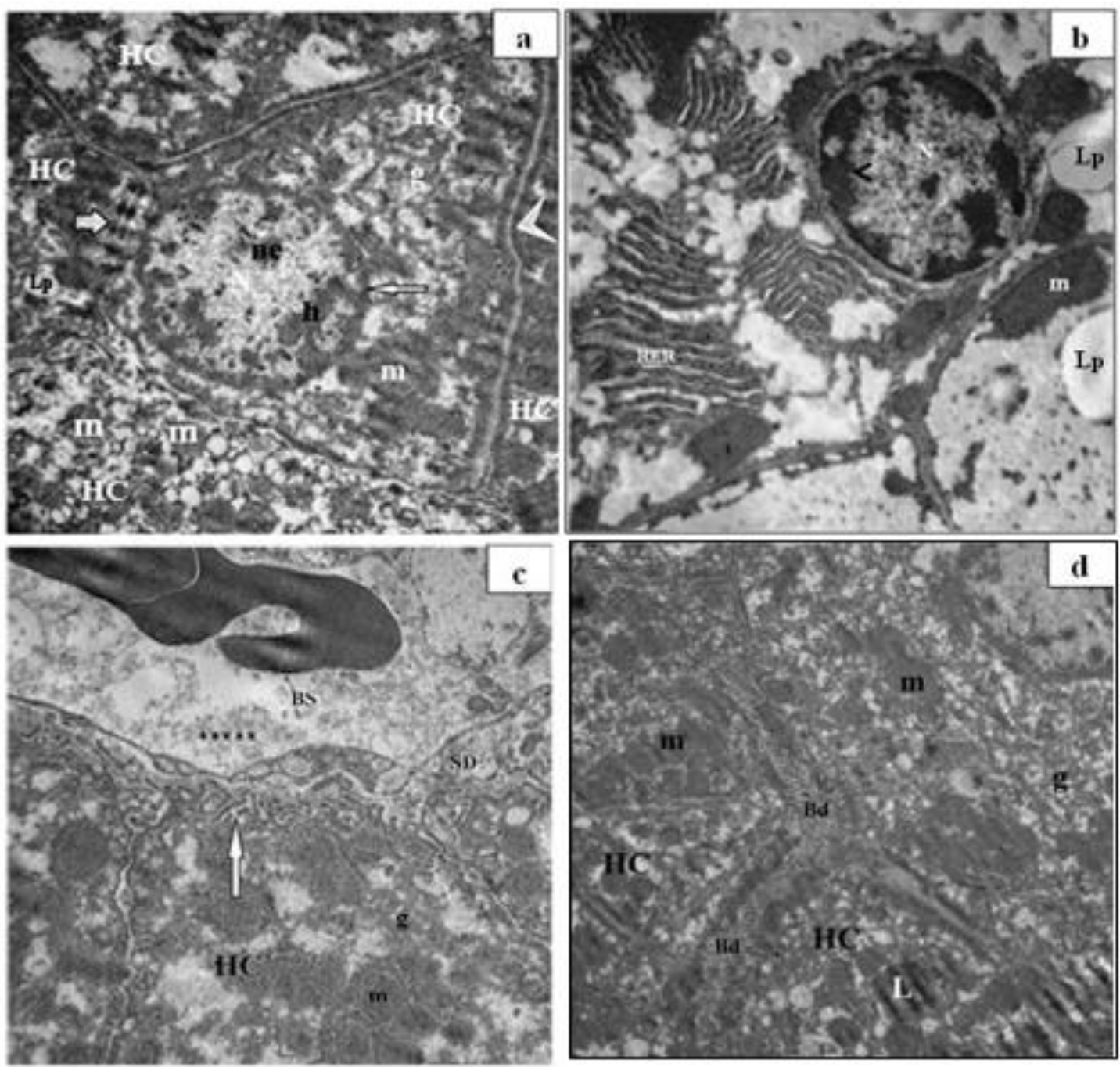

Fig. 2. (a) Electron micrograph showing general morphology of hepatocytes (HC). One of them appears with peripherally placed rounded nucleus $(\mathrm{N})$, mitochondria $(\mathrm{m})$, lipid globules (Lp) and glycogen granules $(\mathrm{g})$ and distinct cell membrane (arrowhead). The nucleus has a distinct nuclear envelope (thin arrow), nucleolus (ne) and heterochromatin (h). Also, junctional complexes (thick arrow) are discerned between the cell membranes. (b) E. Micrograph of hepatic cells showing abundant of the rough endoplasmic reticulum (RER) near, mitochondria (m) and lipid globules (Lp). Also, rounded nuclei (N) with a well discernible nuclear envelope and clumped chromatin at the periphery (arrowhead) can be observed. (c) Electron micrograph showing blood sinusoid containing RBCs and blood plasma $(*)$. Fenestrated endothelial cells (En), space of Disse (SD) containing the microvilli (arrow) of the hepatic cells (HC) were also noticed. The hepatocyte contains mitochondria (m) and glycogen granules (g). (d) E. micrograph of liver section showing prominent bile canaliculi $(\mathrm{Bd})$. Large numbers of mitochondria $(\mathrm{m})$ and lysosomes $(\mathrm{L})$ besides rosettes-like glycogen granules $(\mathrm{g})$ are present. (Direct magnification for $\mathrm{a}=(7200 \mathrm{x})$; $\mathrm{b} \& \mathrm{c}=(10000 \mathrm{x})$; $\mathrm{d}=(5800 \mathrm{x})$. 

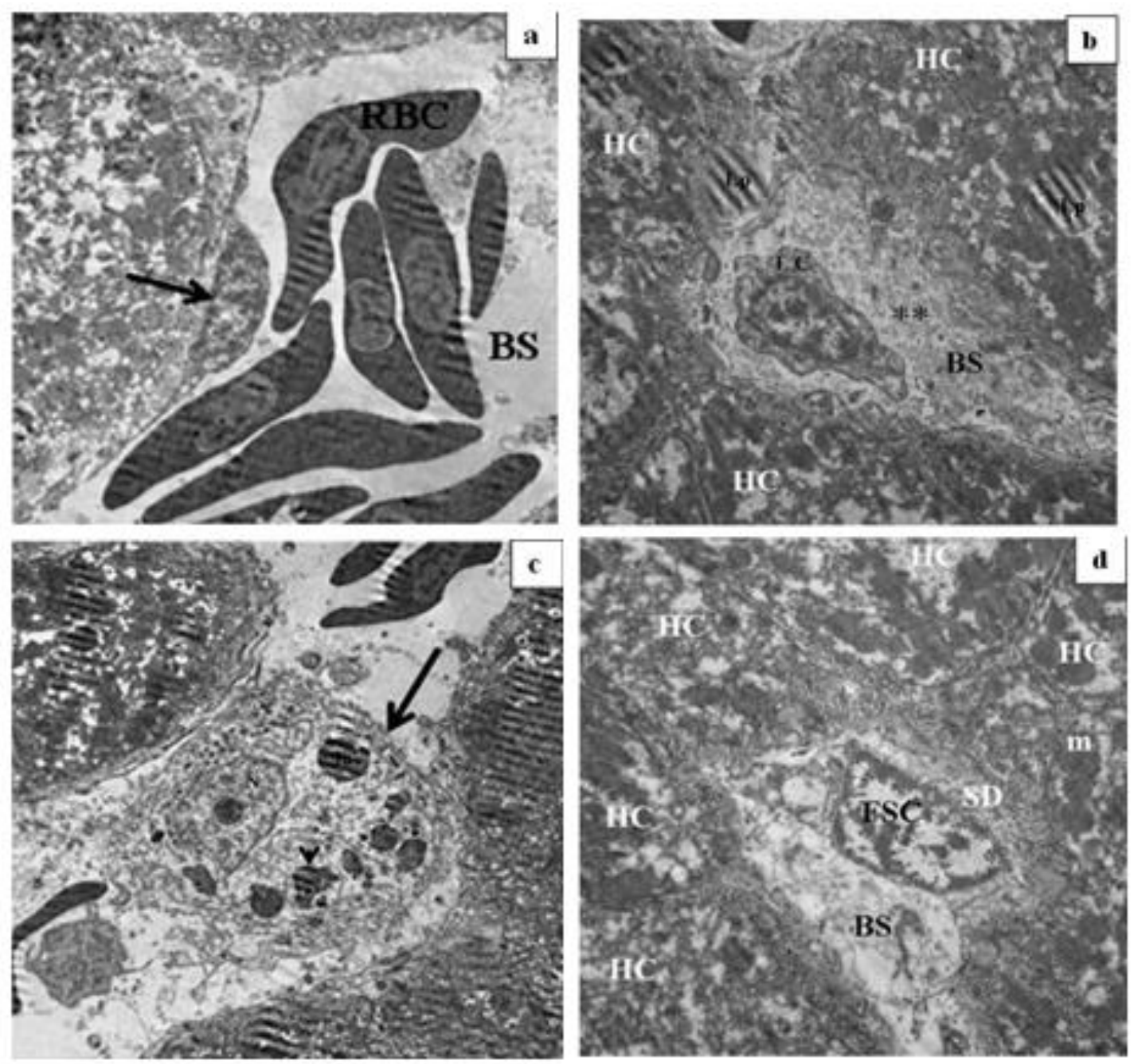

Fig. 3. (a) E. micrograph of the hepatic sinusoids (BS) containing red blood cells (RBC) and lined by fenestrated endothelial cells (arrow). (b) E. Micrograph of the liver section showing hepatocytes (HC) and hepatic sinusoids (BS). Lymphocytes (LC) and blood plasma (*) present in hepatic sinusoids have appeared. The hepatic cell (HC) contains lipid globules (Lp). (c) E. micrograph of the liver section showing Kupffer cell (arrow) having many pseudopods, nucleus (N), and cytoplasm containing numerous electron-dense lysosomes (arrowhead). (d) E. micrograph of hepatic sinusoids space (BS) showing fat storing cell (FSC) in the space of Disse (SD). Hepatic cells (HC) contain numerous mitochondria $(\mathrm{m})$. (Original magnification for $a \& b=(4800 x) ; c=(3600 x) ; d=(5800 x$

\section{DISCUSSION}

In reptiles, the liver is the largest extrinsic digestive gland and is the site of initial processing of materials absorbed by intestinal capillaries and transported via tributaries of the hepatic portal vein (Schaffner, 1998). This visceral organ is large and singular and can have various shapes depending on the visceral cavity. In snakes and some lizards, it is long and thin while it is thick and more compact in some other reptile species (Starck and Beese, 2002).
The hepatocyte-sinusoidal structure is physiologically important, not only because hepatocytes take up large molecules from the sinusoid, but also because a large number of macromolecules (e.g., lipoproteins, albumin and fibrinogen) are secreted into the sinusoid. We detected that the hepatocytes are arranged in multi-cellthick cords or plates along the narrow and short tortuous sinusoids. Our finding is in accordance with reports confirmed that the sinusoids are capillary networks which are localized 
in the spaces between hepatic plates (Rappaport, 1963).

Also, we observed that the hepatic plates are arising from the central vein to the lobular periphery and the radial arrangement of hepatic cords around the central vein is generally not apparent. This finding was provided good support from the reports of Jacobson (2007) who found that in the snake, a radial arrangement of hepatic plates around a central vein is generally not apparent. In the microscopical examination, we found a several-cell-thick plate of hepatocytes separated by narrow and short tortuous sinusoids. This finding agreed with Akiyoshi and Inoue (2004) who observed in the fish's liver the hepatic plate's line multi-layered hepatocytes, the so-called solid or tubular types.

Moreover, we detected in the liver tissue a portal triad which comprised of bile duct accompanied by a portal vein and hepatic arteriole. This finding is in the same line with Motta (1984) who speculated that the portal triad contains branches of the portal vein, hepatic artery, and bile duct, lymph vessels and nerves. These vessels and ducts are surrounded by connective tissue.

Also, the examination of the Acanthodactylus boskianus liver showed a mild amount of connective tissue stroma around the central vein as well as the sinusoidal walls and each portal area. These findings are in accordance with those displayed in the liver of some lizards, by some researchers who revealed that the parenchyma is supported by connective tissue stroma that surrounds the hepatocytes as well as blood sinusoids and portal area (Firmiano et al, 2011; Koca et al., 2004; Moura et al., 2009).

In all the staining techniques utilized, we detected pigment- containing cells called melanomacrophages. This finding was reinforced by those observations confirmed that the melanomacrophages are components of an internal, pigmented cell system in the liver and spleen tissues of some fishes, anurans and reptiles (Manera et al., 2000; Sichel et al., 2002; Agius and Roberts, 2003; Zieri et al., 2007). In the same concern, Frye (1991) reported that these cells are numerous in amphibians and reptiles, except among snakes, in which they are less plentiful. These cells have various functions among them synthesis of melanin, phagocytosis and neutralization of free radicals (Sichel et al., 2002; Guida et al., 2004). Thus, these cells are beneficial for poikilotherms, since they are not present in birds or mammals (Kardong, 2005).

$$
\text { Lamers and De Haas (1985) }
$$
further emphasized the close relationship of melano-macrophages cells with the lymphoid cells and suggested that they were the major sites of long-term antigen retention. It has been suggested that both functional and structural grounds melano-macrophages cells may represent the primitive analogues of the germinal centers of the lymph nodes of birds and mammals. Clinical studies have shown the association of melano- macrophages cells with a range of highly resistant intracellular bacteria and parasites (Roberts, 2001).

The fine structural organization of the hepatocytes of Acanthodactylus boskianus was similar to that reported for other reptilian species (deBritoGitirana and Rangel, 1995). In the present work, we found that, the hepatic cells of Acanthodactylus boskianus are polygoanal in shape and similar to those of other vertebrates, except for the melano-macrophages. This observation received marked 
support from the reports which mentioned that the hepatic cells of lizards are similar to those of other vertebrates, except for the melanomacrophages, which are absent in birds and mammals (Sichel et al., 2002; Agius and Roberts, 2003).

Also, we observed that the nuclei located at the periphery of the hepatic cells. This finding agreed with the same observation that was reported for Phrynops geoffroanus (Moura et al., 2009) and for Tropidurus torquatus (Firmiano et al., 2011). These researchers observed that some nuclei located in the central region of the hepatic cells, but most of them were displaced toward the periphery. The nuclei of the liver cells of Acanthodactylus boskianus were displaced to the periphery owing to the presence of various sized abundant vacuole within the cytoplasm.

In addition, in our study, we noticed numerous rounded mitochondria as well as an abundace of the rough endoplasmic reticulum. Our results agreed with reports confirmed that an increase in the number of mitochondria in cold temperature occurs in mice, hamster and bat liver (Horwitz, 1976), and muscle of squirrel during hibernation (Moreland, 1962) and in the liver carp (Storch, 1984). In addition, de BritoGitirana and Storch (2002) reported that hepatocytes react to the reduction in temperature with an increase in the endoplasmic reticulum and in the number of mitochondria and peroxisomes. The same authors found that rough endoplasmic reticulum (rER) was better developed in animals kept at a lower temperature $\left(20^{\circ} \mathrm{C}\right)$ than in animals at $35^{\circ} \mathrm{C}$. Our findings were interpreted by the opinion of (de Brito-Gitirana and Storch, 2002) who stated that in the cold, the augmentation in the number of mitochondria and the endoplasmic reticulum, the enhancement in activity of the Golgi apparatus, the increase in the number of ribosomes on the nuclear envelope, and the formation in groups of peroxisomes may represent a morphological denotation in order to a biochemical compensation to process temperature adaptation.

Ito (1951) observed cells containing lipid droplets in the human liver lobules. These cells were located in the space of Disse and were surrounded by reticular fibers. He presumed that lipid droplets in these cells were derived from the blood stream and designated these cells (fat-storing cells). The existence of the fat- storing cells was reported in fishes, amphibians, reptiles, birds and mammals (Ito et al., 1962) and man (Ito and Shibasaki, 1968). Variations in the number of lipid droplets have been reported in different seasons (Ito et al., 1960) and under some nutritional conditions (Kitagawa, 1960).

As in mammals, the Kupffer cell serves as a sinusoidal macrophage and free radical scavengers and the Ito cell is the main storage site of vitamin A (Scalia et al., 1988).

There are 3 morphologically and functionally distinct surfaces of the hepatocyte plasma membrane.

1.The sinusoidal domain faces the space of Disse and has numerous irregular microvilli, increasing hepatocyte surface area by $\sim 6$-fold (Wisse, 1970). This specialized membrane is modified to facilitate an exchange of substances with the blood. There are ultrastructurally evident pits between the villi, some of which represent secretory vacuoles in the process of exocytosis, sending various products into the plasma, and others are clathrin-coated pits involved in selective receptormediated endocytosis. 
2.The lateral domain extends from the sinusoidal surface to the edge of the canaliculus. This portion of the cell membrane is specialized for adhesion via junctional complexes, including desmosomes, tight junctions, and intermediate junctions, as well as for intercellular communication via gap junctions (Kitagawa, 1960).

3. The canalicular domain is the beginning of the bile drainage system of the liver. The canaliculus is an intercellular space between 2 adjacent hepatocytes, isolated by junctional complexes. The canalicular surface is covered with an irregular array of microvilli (Tanaka, 1960).

The presence of lipid droplets within the liver cells of Acanthodactylus boskianus could be attributed to an adaptive structural modification to sustain the storage functions of the liver as previous studies had earlier indicated that the liver stored several substances including glycogen, lipids, vitamins and iron (Barbara et al., 2014; Singh, 2014). Also, previous studies showed that the fat droplet seen in reptiles could be converted (gluconeogenesis) and used as energy in unfavorable weather or dormancy (Akiyoshi and Inoue, 2004).

Concerning of the carbohydrates material, we found under the electron microscope the polysaccharide, glycogen, takes the form of small particles distributed diffusely throughout the cytoplasm. This finding agreed with those observed in Trachomys scripta elegans (Marycz et al., 2009), in which the results indicated an abundance of glycogen in the cytoplasm. Also, according to (DA Silva and Migliorini, 1990), this is a characteristic commonly found in healthy individuals, since the stock of hepatic glycogen is the main reserve energy source, drawn on during prolonged fasting.

Regarding the glycogen content, several interpretations are available in the literature. Storch et al. (1962) reported that the liver of carp, adapted to cold temperature, displays a high content of glycogen. In some species of fish, the glycogen increases with the decrease of temperature (Rafael and Braunbeck, 1987). In conclusion, from the morphological description of the liver of Acanthodactylus boskianus it can be concluded that this species an excellent model for histological studies of this class.

\section{Acknowledgment}

We would like to thank Dr. Sherif Baha El Din, Environmental Consultant, Ecologist, Ornithologist, Herpetologist, and President Nature Conservation Egypt for his help in lizard identification.

\section{REFERENCES}

Agius, C., Roberts, R.J. (2003): Melano-macrophage centres and their role in fish pathology. Journal of fish Diseases, 26: 499509.

Akiyoshi, H., Inoue, A. (2004): Comparative histological study of teleost livers in relation to phylogeny. Zool Sci., 21:841-50.

Motta, P.M. (1984): The threedimensional microanatomy of the liver. Arch Histol Jap., 47: 1- 30.

Audouin, J.V. (1827): Explication sommaire des planches de reptiles (supplément) offrant un exposé des characters des espèces. In: Savigny MJCL, ed. Description de l'Égypte, Vol. 1, Histoire Naturelle. Paris: Impériale, 161184.

Boulenger G.A. (1919): On a new variety of Acanthodactylus boskianus Daud., from the Euphrates. The Annals and Magazine of Natural History, 3: 549-550. 
Boulenger G.A. (1878): Sur les espèces d'Acanthodactylus des bords de la Mediterranée. Bulletin de la Société zoologique de France, 3: 179- 197.

Barbara, Y., Geraldine, O., Phillip, T. (2014): Histology of the Digestive Tract: Wheater's Functional Histology. 11th ed. Philadelphia: Elsevier, Churchill Living Stone p. 274-80.

Daudin, F.M. (1802): Histoire naturelle, générale et particulière, des reptiles: ouvrage faisant suite à l'Histoire naturelle générale et particulière. F. Dufart.

de Brito-Gitirana, L., Storch, V. (2002): Temperature induced alterations in the liver of wall lizard (Hemidactylus frenatus): morphological and biochemical parameters. Micron, 33: 667-672.

de Brito-Gitirana, L., Rangel,

N.V. (1995): Ultrastructural and cytochemical aspects of hepatic peroxisomes of the Brazilian snake (Bothrops jararaca, Wied 1824. Eur J Cell Biol., 179: 61.

DA Silva, S.M., Migliorini, R.H. (1990): Effects of starvation and refeeding on energy-linked metabolic process in the turtle (Phrynops hilarii). Comparative Biochemistry and Physiology, 96(A): 415-419.

Frye, F.L. (1991): Reptile care: An atlas of diseases and treatments. Neptune: TFH Publications, 324p.

Firmiano, E.M.S., Cardoso, N.N., Vieira, D.A., Sales, A., Santos, M.A.J., Mendes, A.L.S., Nascimento,(2011): Histological study of the liver of the lizard Tropidurus torquatus Wied 1820, (Squamata: Tropiduridae). J Morphol Sci., 28 (3): 165-170.

Guida, G., Zanna, P., Gallone, A., Argenzio, E., Cicero, R. (2004): Melanogenic Response of the kupffer Cells of Rana esculenta L. to Melanocyte Stimulating Hormone. Pigment Cell Research, 17: 128-134.

Harris, H.F. (1990): On the rapid conversion of haematoxylin into haematin in staining sections. J Appl Micros Lab Meth, 3: 777781.

Horwitz, B.A. (1976): The effect of cold exposure on liver mitochondrial and peroxisomal distribution in the rat, hamster and bat. Comp Biochem Physiol., 54a: 45-48.

Hamdi, H., El-Ghareeb, A., Zaher, M., Essa, A., Lahsik, S. (2014): Anatomical, Histological and Histochemical Adaptations of the Reptilian Alimentary Canal to Their Food Habits: IIChamaeleon africanus. World Applied Sciences Journal, 30 (10): 1306-1316.

Ito, T. (1951): Cytological studies on stellate cells of Kupffer and fat storing cells in the capillary wall of the human liver (Japanese abstract). Acta Anar Nippon., 26: 42.

Ito, T., Watanabe, A., Takahashi, Y. (1962): Histologische und cytologische Untersuchungen der Leber bei Fisch und Cyclostoma, nebst Bemerkungen uber die Fettspeicherungszellen. Arch histol Jap., 22: 429-463.

Ito, T., Shibasaki, S. (1968): Electron microscope study on the hepatic sinusoidal wall and the fat- storing cells in the normal human liver. Arch Hisrol Jap., 29: 137-192.

Ito, T., Shibasaki, S., Kitamura, T. (1960): Experimental-morphologische Untersuchungen Uber die jahreszeitlichen Veranderungen der Leberfunktion bei dem Sauger. Hungerversuche an Kaninchen. Arch histol Jap., 20: 629-654. 
Jacobson, E.R. (2007): Overview of reptile biology, anatomy and histology, In Infectious Diseases and Pathology of Reptiles; Jacobson ER, Ed, Taylor and Francis, London, UK, 1-2.

Kardong, K.V. (2005): Comparative Anatomy of Associated Glands of Digestion, Vertebrates, Comparative Anatomy. 4th ed. New York, Hata: McGraw-Hill p13.

Kitagawa, T. (1960): Histologische and cytologische Untersuchungen uber die Huhnerleber nebst Bemerkungen der Fettspeicherungszellen (fatstoring cells). (Japanese text with German abst.). Arch histol jap. 18: 493-538.

Koca, Y.B., Gúrcú, B., Balcan, E. (2004): The histological investigation of liver tissues in Tritures karelinií and Tritures vulgaris (Salamandridae, Urodela). Russian Journal of Herpetology, 11 (3): 223-229.

Lillie, R.D. (1940): Further experiments with the Masson trichrome modification of Mallory's connective tissue stain. Stain Technol, 15: 17.

Lamers, C.H.J., DE Haas, M.J.H. (1985): Antigen localisation in the lymphoid organs of carp (Cyprinus carpio). Cell and Tissue Research, 242: 491-498.

Mc Manus, J.P.A. (1946): Histological demonstration of mucin after periodic acid. Nature (London), 158(4006): 202.

Moreland, J.E. (1962): Electron microscopic studies of mitochondria in cardiac and skeletal muscle from hibernated ground squirrels. Anat Rec., 142: $155-168$.

Marycz, K., KlećkowskA-nawrot, J., Maksymowicz, K., Wojciechowicz, E. (2009):
Topographic and macroscopic characteristics of liver in redeared turtle (Trachomys scripta elegans) after hibernation. Part I. Electronic Journal of Polish Agricultural Universities 12 (2).

Manera, M., Serra, R., Isani, G., Carpené, E. (2000): Macrophage aggregates in gilthead sea bream fed copper, iron and zinc enriched diets. Journal of Fish Biology, 57: 457-465.

Moura, L.R., Santos, A.L.Q., Belleti, M.E., Vieira, L.G., Orpinelli, S.R.T., De Simone, S.B.S. (2009): Morphological aspects of the liver of the freshwater turtle Phrynops geoffroanus Schweigger, 1812 (Testudines, Chelidae). Brazilian Journal Morphological Sciences, 26 (3-4): 129-134.

Pough, F., Heiser, J., Mcfarland, W. (1999): A vida dos vertebrados. 2th ed. São paulo: atheneu editora, 802.

Schaffner, F. (1998): The liver. In: GANS, C., ed. visceral organs. Philadelphia: Saunders, 485-531.

Rastegar-Pouyani, N. (1998): A new species of Acanthodactylus (Sauria: Lacertidae) from Qasr-eShirin, Kermanshah Province, western Iran. Proceedings of the California Academy of Sciences, 50: 257-265.

Rappaport, A.M. (1963): Anatomical considerations. In: Schiff ER, Sorrell MF, Maddrey WC, editors. Schiff's Diseases of the Liver. $10^{\text {th }}$ ed. Philadelphia: Lippincott Wilkins \& Williams, p. 1-46.

Rafael, J., Braunbeck, T. (1987): Interacting effects of diet and environmental temperature on biochemical parameters in the liver of Leuciscus idus melanotus (Cyprinidae: Teleostei). Fish Phys Biochem., 5: 9-19. 
Roberts, R.J. (2001). Fish Pathology. $\quad 3^{\text {th }}$ ed.London: W.B. Saunders, 489p.

Singh, I. (2014): Digestive System: Textbook of Human Histology. New Delhi, India: Jaypee Brother's Medical Publishers (P) Lt. p. 249-57.

Starck, J. M., Beese, K. (2002): Structural flexibility of the small intestine and liver of garter snakes in response to feeding and fasting. The Journal of Experimental Biology, 205: 1377-1388.

Sichel, G., Scalia, M., Corsaro, C. (2002): Amphipia Kupffer cells. Microscopy Research and Technique, 57: 477-490.

Samuelson, DA. (2007): Tratado de histologia veterinária. Rio de Janeiro: Elsevier, 527.

Salvador, A. (1982): A revision of the lizards of the genus Acanthodactylus (Sauria: Lacertidae). Bonn: Zoologisches Forschungsinstitut und Museum Alexander Koenig.

Sindaco, R., Jeremc`enko, V.K. (2008): The reptiles of the Western Palearctic. Latina: Edizioni Belvedere.

Trape, J.F., Trape, S., Chirio, L. (2012): Lézards, crocodiles et tortues d'Afrique occidentale et du Sahara. Marseille: IRD Orstom.

Storch, V., Jua'rio, J.V., Pascual, F.P. (1984): Early effects of nutritional stress on the liver in milkfish Chanos chanos (Forsskal) and on the hepatopancreas of the tiger praw Penaeus monodon (Fabricius). Aquac., 36: 229-236.

Scalia, M., Geremia, E., Corsaro, C., Santoro, C., Sciuto, S., Sichel, G. (1988): The extracutaneous pigmentary system: evidence for the melanosynthesis in Amphibia and Reptilia liver. Comparative
Biochemistry and Physiology Part

B: Comparative Biochemistry, 89 (4): 715-717.

Tamar, K., Carranza, S., Sindaco, R., Moravec, J., Meiri, S. (2014): Systematics and phylogeography of Acanthodactylus schreiberi and its relationships with Acanthodactylus boskianus (Reptilia: Squamata: Lacertidae). Linnean Society of London, Zoological Journal of the Linnean Society, 1-20.

Tanaka, Y. (1960): Cytologische und histologische Untersuchungen uber die Leber bei den Sperlingen mit besonderer Berucksichtigung der jahreszeitlichen Veranderungen und der Fettspeicherungszellen (fat- storing cells). Arch histol Jap., 19: 145-188.

Uetz, P. (2013): The reptile database. Available at: http://www.reptiledatabaseorg/

Uetz, P., Hallermann, J. (2010): The JCVI/TIGR Reptile Database. Available from: <http://www.reptiledatabase.org>.

Vitt, L.J., Pianka, E.R., Cooper-junior, W.E., Schwenk, K. (2003): History and the Global Ecology of Squamate Reptiles. American Naturalis, 162 (1): 44-60.

Wisse, E. (1970): An electron microscopic study of the fenestrated endothelial lining of rat liver sinusoids. J Ultrastruct Res., 31: 125-150.

Zieri, R., Taboga, S.R., Oliveira, C. (2007): Melanocytes in the testes of Eupemphixnattereri (Anura, Leiuperidae): histological, stereological and ultrastructural aspects. The Anatomical Record, 290: 795800. 


\title{
ARABIC SUMMARY
}

\author{
Acanthodactylus boskianus دراسات ميكروسكوبية على كبا سحلية \\ علام عبد الحميد نفادى 1 ـاعتماد أحمد عوض الله 2* \\ 1 قسم الباتولوجى -كلية الطب البيطرى - جامعة أسيوط \\ 2*قسم علم الحيوان - كلية العلوم - جامعة أسوان البطري
}

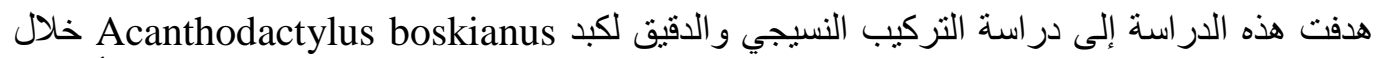

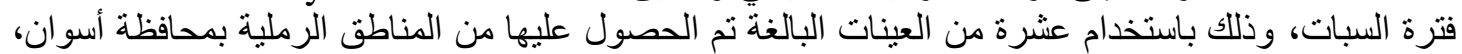

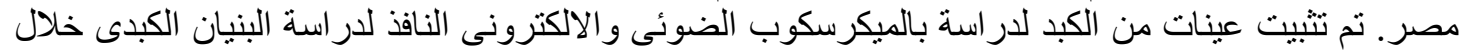

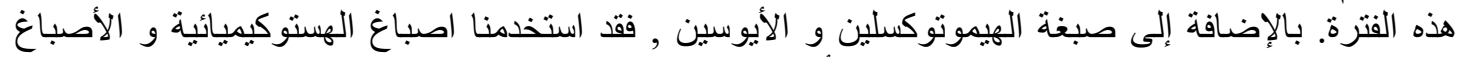

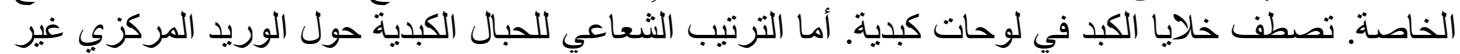

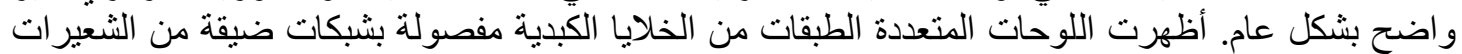

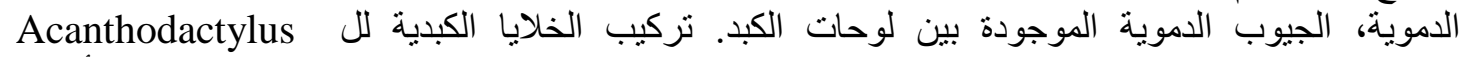
boskianus (الطيور و الثثييات) ، باستثناء وجود melano-macrophages. 